Original Research Paper

\title{
Pertumbuhan, Mortalitas dan Tingkat Pemanfaatan Kerang Pokea (Batissa violacea var. celebensis von Martens, 1897) di Sungai Laeya Konawe Selatan Provinsi Sulawesi Tenggara
}

\author{
Sitti Nurlailah Basri ${ }^{1 *}$, Bahtiar $^{1}$, La Anadi ${ }^{1}$ \\ ${ }^{1}$ Program Studi Ilmu Perikanan, Pasca Sarjana Universitas Halu Oleo, Kendari, Sulawesi Tenggara, Indonesia
}

Article history

Received: 18 Februari 2019

Revised: 25 Februari 2019

Accepted: 28 Februari 2019

Published: 04 Maret 2019

*Corresponding Author:

Sitti Nurlailah Basri

${ }^{1}$ Program Studi Ilmu Perikanan, Pasca Sarjana Universitas Halu

Oleo, Kendari, Sulawesi

Tenggara, Indonesia

Email:

nurlailahsitti07@gmail.com
Abstract : Pokea clam are one of the potential resources and have an important role both ecologically and economically. One of areas suitable for the life of this clam is the laeya river. This research aimed to determine growth, mortality and eksploitation rate of Pokea clam on the Laeya River in South Konawe which was started in September 2016 - February 2017. This research used swept area method by using a catching tool namely tangge. Data were growth, mortality and the exploitation level was analysed using Bhattacharya method, inverse von Bertalanffy, width converted catch curve and empirical Pauly, accommodated in FiSAT II version 3.0. The total sample of pokea clam during the research were 849 individuals. The result of growth analysis showed that the asymptotic width value $(\mathrm{L} \infty)$, growth constant $(\mathrm{K})$, estimated value $t_{0}$ for the growth of pokea clam was 7,41, 0,56 and $-0,38$. The result of estimation analysis for the level of morality showed that the natural mortality value $(\mathrm{M})$ was 1,84 , the catching mortality $(\mathrm{F})$ was 1,19 , and the total mortality $(\mathrm{Z})$ was 3,03 . The exploitation rate (E) was 0,39 which shows the level exploitation rate of pokea clam in the waters of the Laeya River was still relatively low (under fishing).

Keywords : Pokea Clam, Laeya Rivers, Growth, Mortality, Exploitation Rate

Abstrak : Kerang pokea merupakan salah satu sumberdaya potensial dan mempunyai peranan penting baik secara ekologis maupun ekonomis. Salah satu wilayah yang cocok untuk kehidupan kerang ini adalah Sungai Laeya. Penelitian ini bertujuan untuk mengetahui pertumbuhan, mortalitas dan tingkat pemanfaatan kerang pokea di Sungai Laeya Konawe Selatan yang dimulai pada bulan September 2016 - Februari 2017. Metode penelitian yang digunakan adalah luas sapuan (swept area method) dengan memakai alat tangkap tangge. Data pertumbuhan, mortalitas dan tingkat eksploitasi masingmasing menggunakan metode Bhattacharya, model inverse von Bertalanffy, hasil tangkapan yang dikonversi dari data lebar cangkang dan empiris Pauly yang terakomodasi dalam program FiSAT II versi 3.0. Total sampel kerang pokea selama penelitian sebesar 849 individu. Hasil analisis pertumbuhan menunjukan nilai lebar asimtotik $(\mathrm{L} \infty)$, konstanta pertumbuhan $(\mathrm{K})$, nilai dugaan $\mathrm{t}_{0}$ pada pertumbuhan kerang pokea masing-masing $7,41,0,56$, dan 0,38 . Hasil analisis pendugaan tingkat mortalitas menunjukkan nilai mortalitas alami (M) 1,84, mortalitas penangkapan (F) 1,19, dan mortalitas total (Z) 3,03. Tingkat eksploitasi (E) yaitu 0,39 yang menunjukkan tingkat eksploitasi kerang pokea di perairan Sungai Laeya masih tergolong rendah (under fishing).

Kata Kunci : Kerang Pokea, Sungai Laeya, Pertumbuhan, Mortalitas, Tingkat Eksploitasi 


\section{Pendahuluan}

Sulawesi Tenggara merupakan daerah yang memiliki keanekaragaman hayati cukup tinggi diantaranya ialah keanekaragaman hayati pada tingkat ekosistem air tawar. Salah satu jenis dari ekosistem air tawar adalah ekosistem lotik contohnya Sungai Laeya yang terdapat di Konawe Selatan. Sungai ini dimanfaatkan masyarakat dalam berbagai peruntukkan dalam pemenuhan kebutuhan hidupnya. Disisi lain, sungai ini memiliki potensi sumberdaya hayati diantaranya adalah jenis kerang air tawar yang masyarakat sekitarnya menyebutnya dengan nama pokea (Batissa violacea var. celebensis, von Martens 1897).

Kerang pokea memiliki dua arti penting dalam sumberdaya yaitu dalam sisi ekologi dan sisi ekonomi. Sisi ekologi, kerang pokea memiliki manfaat sebagai penyeimbang dalam ekosistem lingkungannya. Sisi ekonomi, kerang pokea telah dikenal sebagai sumber makanan yang lezat dan bergizi, cangkangnya dapat menjadi perhiasan rumah tangga dan bahan bangunan (Bahtiar, 2005).

Masyarakat di sekitar perairan Sungai Laeya secara umum dalam kesehariannya memanfaatkan berbagai macam sumberdaya hayati yang ada di perairan Sungai Laeya sebagai sumber pangan. Selain berbagai jenis ikan yang ada, mereka juga mencari kerang-kerangan salah satunya yaitu kerang pokea untuk dimakan dan dijual dengan cara menangkap kerang tersebut. Adanya aktivitas masyarakat yang memanfaatkan kerang pokea secara terus menerus akan memberikan pengaruh atau dampak bagi organisme tersebut (Islami, 2014).

Disamping terjadi penurunan populasi kerang pokea akibat penangkapan, juga terjadi tekanan terhadap kondisi habitat alami. Sumberdaya pokea juga akan berkurang karena adanya penurunan kualitas lingkungan akibat kerusakan habitat yang dilakukan oleh berbagai aktivitas masyarakat sekitar daerah aliran sungai, seperti adanya aktivitas penambangan nikel di bagian atas sungai (up land) dan aktivitas penambangan pasir dibeberapa tempat di sungai ini yang dilakukan secara terus menerus sehingga dapat mengganggu laju pertumbuhan kerang pokea. Tekanan yang diterima dapat mengakibatkan berkurangnya populasi kerang pokea di Sungai Laeya. Bila kondisi tersebut berlangsung secara terus menerus dalam kurung waktu tertentu, maka akan mengakibatkan kepunahan kerang tersebut. Dengan demikian, kegiatan penangkapan kerang pokea dan aktivitas penambangan dapat memengaruhi dan mengubah status stok sumberdaya kerang pokea terutama di perairan Sungai Laeya (Natan, 2009).

Penelitian mengenai beberapa parameter populasi kerang saat ini sudah banyak dilakukan, termasuk Indonesia diantaranya kajian populasi pokea di Sungai Pohara Kendari (Bahtiar 2005); Analisis populasi dan habitat sebaran ukuran dan kematangan gonad kerang lokan di Muara Sungai Batang Anai Padang Sumatera Barat (Putri, 2005); Kepadatan populasi dan pertumbuhan kerang darah di Teluk Sungai Pisang, Sumatera Barat (Nurdin et al., 2006); Kajian aspek pertumbuhan pokea di Sungai Pohara Sulawesi Tenggara (Bahtiar et al., 2008); Studi bioekologi dan dinamika populasi pokea di Sungai Pohara Sulawesi Tenggara (Bahtiar, 2012); Pertumbuhan, kematian dan tingkat eksploitasi kerang coklat di perairan Teluk Kendari (Nasrawati et al., 2016); namun untuk aspek pertumbuhan, mortalitas dan tingkat pemanfaatan kerang pokea di perairan Sungai Laeya baru yang pertama kali dilakukan. Dengan adanya penelitian ini diharapkan kemampuan populasi untuk tetap tersedia di alam dapat diketahui. Selain itu bagi para pengambil kebijakan informasi ini dapat dijadikan sebagai acuan untuk pengelolaan secara lestari agar manfaatnya dapat dirasakan secara berkelanjutan.

Penelitian ini bertujuan untuk mengetahui pertumbuhan, mortalitas dan tingkat pemanfaatan kerang pokea untuk dijadikan sebagai dasar informasi penting untuk pengelolaan populasi kerang pokea berkelanjutan di Sungai Laeya Konawe Selatan.

\section{Bahan dan Metode}

Penelitian ini dilaksanakan selama 6 bulan (September 2016 - Februari 2017) yang dilakukan dua tahap, yaitu 1) pengambilan sampel dilakukan di segmen muara Sungai Laeya, Konawe Selatan, Sulawesi Tenggara, dan 2) pengukuran sampel kerang pokea yang dilakukan di Laboratorium Fakultas Perikanan Universitas Halu Oleo. 


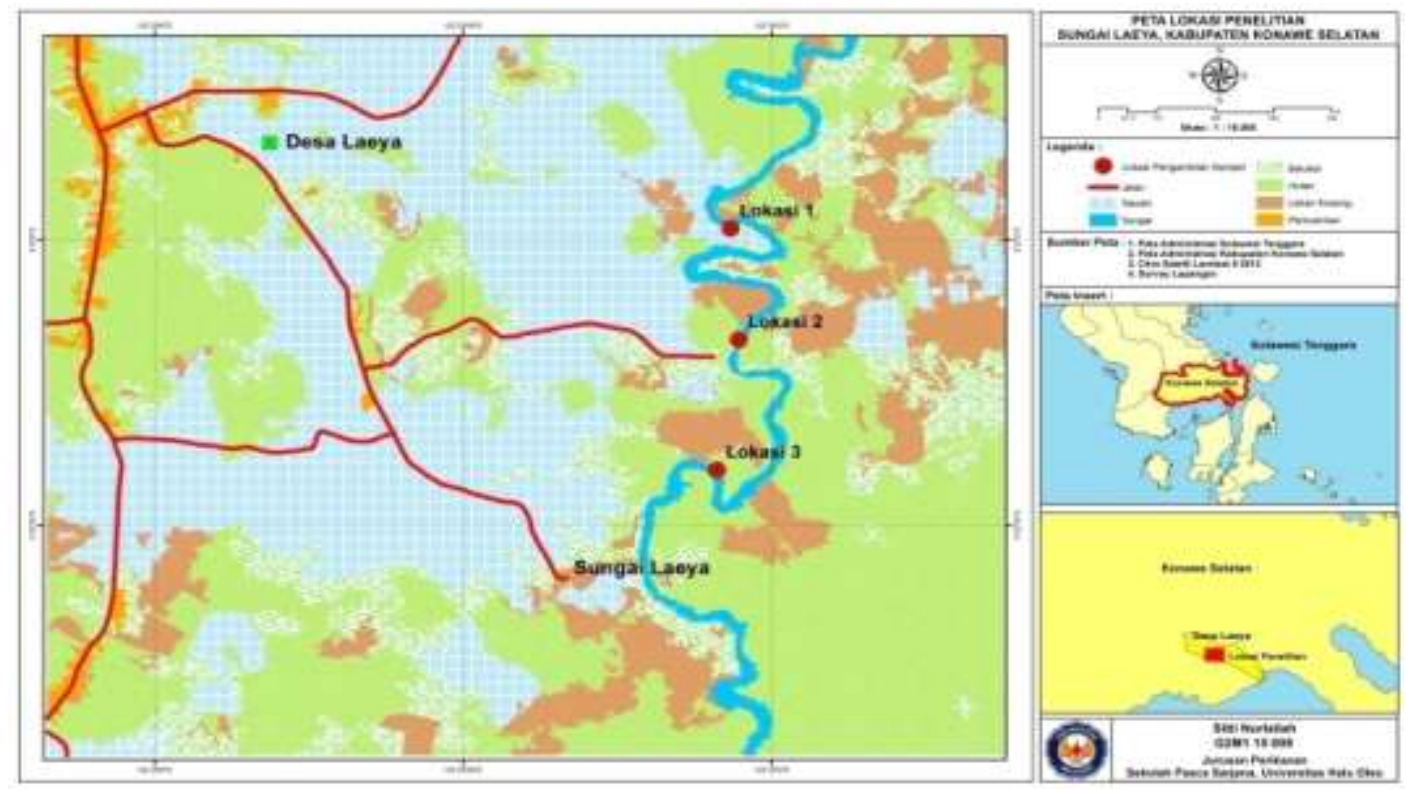

Gambar 1. Peta lokasi penelitian di Sungai Laeya

Metode penelitian yang digunakan adalah luas sapuan (swept area method) dengan memakai alat tangkap yang sering digunakan oleh masyarakat yaitu alat tangkap tangge (alat tangkap tradisional). Alat ini dioperasikan oleh 2 orang nelayan di atas sebuah perahu. Tangge merupakan alat yang terdiri atas keranjang besi, bambu panjang dan tali. Keranjang tersebut terbuat dari kawat baja dengan panjang $25 \mathrm{~cm}$ dan bukaan mulut $20 \mathrm{~cm}$ dengan ukuran mata keranjang lebih kurang $1 \times 1 \mathrm{~cm}$. Pada bagian mulut keranjang dikelilingi dengan besi baja tipis sehingga memudahkan alat ini untuk menembus substrat sedangkan keranjang dihubungkan dengan tali untuk memudahkan penarikan alat tersebut ke permukaan dengan posisi keranjang ditempatkan pada bagian ujung bambu. Sungai yang dalam menyebabkan alat ini menggunakan bantuan bambu dengan panjang lebih kurang 10 meter. Pokea yang tertangkap kemudian dipisahkan dari sedimen dasar dan menghitung jumlah individu pokea yang diperoleh dari setiap tarikan alat di setiap stasiunnya.

Pengambilan sampel kerang pokea dilakukan sekali sebulan selama 6 bulan pada 3 lokasi pengambilan. Jumlah tarikan pengambilan sebanyak 10 kali dalam setiap tempat. Sampel kerang pokea yang diperoleh, dibersihkan lalu dimasukkan ke dalam kantong plastik kemudian dibawa ke laboratorium. Selanjutnya diukur panjang cangkang kerang di laboratorium. Panjang cangkang dapat didefinisikan sebagai jarak dari anterior sampai posterior. Namun ukuran panjang dalam studi dinamika populasi tidak mutlak mengikuti definisi yang sesungguhnya atau ukuran panjang sesungguhnya tidaklah penting sepanjang terdapat teori yang melatar belakangi model pertumbuhan. Berdasarkan hal tersebut, maka panjang cangkang yang digunakan dalam pendugaan parameter populasi adalah lebar cangkang yang diukur dari ujung tepi kanan ke ujung tepi kiri cangkang merujuk pada Sparre dan Venema (1999) dan King (1995). Pengukuran panjang, lebar, dan tebal cangkang dilakukan dengan memakai jangka sorong dengan ketelitian 0,01 mm. Pengukuran parameter kualitas air bersamaan dengan pengambilan sampel.

\section{Analisis Data}

\section{Penentuan Parameter Pertumbuhan}

Parameter pertumbuhan kerang pokea terhitung berdasarkan model inverse pertumbuhan dengan menggunakan analisis von Bertalanffy (Anthony et al., 2001) yaitu:

$$
L t=L_{\infty}-\left(L_{\infty}-L_{0}\right) e^{-K t}
$$

\section{Keterangan:}

Lt = lebar kerang pada umur $\mathrm{t}(\mathrm{cm})$

$\mathrm{L}_{\infty}=$ lebar asimtot/maksimum kerang $(\mathrm{cm})$

$\mathrm{K}=$ koefisien pertumbuhan (per tahun)

Lo $=$ ukuran kerang pada saat larva atau glochidia

$\mathrm{t} \quad=$ umur kerang pada saat Lt (tahun) 


\section{Pendugaan Koefisien Mortalitas}

Koefisien mortalitas total (Z) dapat terduga dengan menggunakan kurva hasil tangkapan konversi lebar (width-converted catch curve), dengan menggunakan paket program FiSAT II versi 3.0 (Gayanilo dan Pauly, 1997) dengan persamaan sebagai berikut:

$$
\ln \left(N_{i} / \Delta t\right)=a+b \cdot t(\overline{L i})
$$

Keterangan :

$\mathrm{Ni}=$ jumlah tangkapan pada setiap kelas ukuran lebar ke-i;

$\Delta \mathrm{t}=$ waktu yang dibutuhkan pokea selama kelas lebar ke-i

$\mathrm{a}$ dan $\mathrm{b}=$ koefisien regresi $(\mathrm{b}=-\mathrm{Z})$

$\mathrm{t}=$ umur yang dihitung dari $\mathrm{t}_{0}=0$

$$
\begin{aligned}
\Delta t & =t(L t+1)-t(\overline{L i}) \\
& =(1 / K) \cdot \ln \{L \infty-L t) /(L \infty-L i+1)\}
\end{aligned}
$$

Keterangan:

Li dan $\mathrm{Li}+1=$ lebar pada kelas ke-i dan lebar pada kelas ke(i+1),

$\mathrm{t}(\overline{\mathrm{Li}}) \quad=$ umur relatif kerang pada kelas lebar ke-i yang dapat terduga dengan rumus:

$$
t(\overline{L i})=t o-(1 / K) \cdot \ln [1-((L i+L i+1) / 2 L \infty)]
$$

Pendugaan terhadap koefisien kematian alami (M) digunakan persamaan empiris (Pauly, 1980) yaitu hubungan antara kematian alami (M) dan parameter pertumbuhan von Bertalanffy $(\mathrm{K}, \mathrm{L} \infty)$ dan suhu rerata lingkungan perairan $(\mathrm{T})$ pokea, yang disajikan sebagai berikut :

$$
\begin{aligned}
\log (M)= & -0,0066-0,279 \log L_{\infty}+0,6543 \log K+ \\
& 0,463 \log T
\end{aligned}
$$

Keterangan :

$\mathrm{M}=$ mortalitas alami

$\mathrm{L}_{\infty}=$ lebar asimtotik $(\mathrm{cm})$

$\mathrm{K}=$ konstanta pertumbuhan

$\mathrm{T}=$ suhu rata-rata $\left({ }^{\circ} \mathrm{C}\right)$

Dengan mengetahui nilai dugaan $\mathrm{Z}$ dan $\mathrm{M}$, maka koefisien mortalitas penangkapan $(F)$ dapat diduga dengan mengurangkan nilai $\mathrm{Z}$ terhadap nilai M.

$$
F=Z-M
$$

\section{Pendugaan Status Eksploitasi}

Pendugaan status eksploitasi (tingkat pemanfaatan) stok dapat diduga dengan rumus (Sparre dan Venema, 1999):

$$
\begin{aligned}
& E=F / Z \\
& \text { atau, } \quad E=F /(F+M)
\end{aligned}
$$

Keterangan :

$\mathrm{E}=$ status eksploitasi

$\mathrm{F}=$ koefisien mortalitas akibat penangkapan

$\mathrm{M}=$ koefisien mortalitas secara alami

$\mathrm{Z}=$ mortalitas total.

Jika,

E > 0,5 menunjukkan tingkat eksploitasi tinggi (over fishing)

$\mathrm{E}<0,5$ menunujukkan tingkat eksplotasi rendah (under fishing)

$\mathrm{E}=0,5$ menunjukkan pemanfaatan optimal. (Sparre dan Venema 1999).

\section{Hasil dan Pembahasan}

\section{Hasil}

\section{Pertumbuhan Kerang Pokea}

Pendugaan parameter pertumbuhan dapat terlihat dengan metode von Bertalanffy dari hasil analisis kelompok ukuran dan didapatkan lebar asimtotik (Lo) dan konstanta pertumbuhan (K) melalui analisis program FiSAT II versi 3.0.

Hasil analisis parameter pertumbuhan kerang pokea berdasarkan data sebaran frekuensi lebar selama 6 bulan menunjukkan nilai ukuran lebar infiniti $(\mathrm{L} \infty)$ yaitu $7,41 \mathrm{~cm}$. Ukuran ini memperlihatkan pertumbuhan cangkang kerang pokea sudah tidak dapat di capai lagi. Nilai koefisien $(\mathrm{K})$ yaitu 0,56 menggambarkan tingkat pertumbuhan kerang pokea untuk mencapai ukuran maksimal serta seberapa cepat pertumbuhan kerang pokea di perairan. Nilai panjang infiniti, koefisien pertumbuhan dan umur pada saat panjang $0 \mathrm{~cm}$ kerang pokea disajikan pada Tabel 1 .

Pertumbuhan lebar kerang pokea sangat cepat terjadi pada umur muda dan dewasa. Pertumbuhan produktif kerang pokea terjadi pada umur 0,46 tahun dengan mencapai lebar cangkang yaitu 4,03 $\mathrm{cm}$. Pertumbuhan kerang pokea akan semakin melambat seiring pertambahan umur sampai mencapai lebar maksimum pada umur 4,33 sampai 13,78 tahun dengan lebar cangkang $7,41 \mathrm{~cm}$ (Gambar 2). 


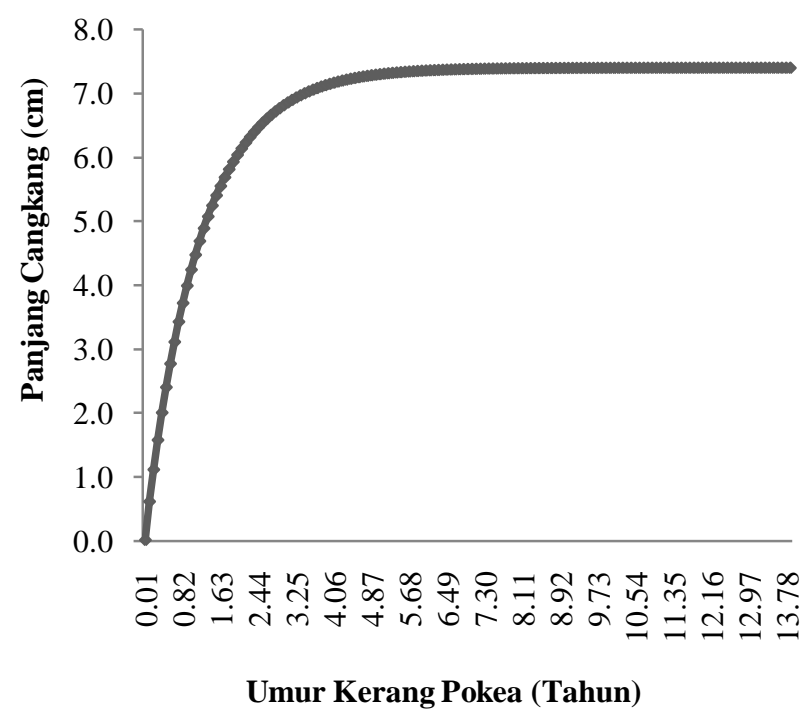

Gambar 2. Laju pertumbuhan kerang pokea

Tabel 1. Parameter pertumbuhan kerang pokea di Perairan Sungai Laeya

\begin{tabular}{ccc}
\hline No. & Parameter & Nilai \\
\hline 1 & $\mathrm{~L} \infty$ & 7,41 \\
2 & $\mathrm{~K}$ & 0,56 \\
3 & $\mathrm{t}_{0}$ & $-0,38$ \\
\hline Keterangan : & L $=$ panjang asimtotik $(\mathrm{cm})$ \\
& $\mathrm{K}=$ konstanta pertumbuhan \\
& $\mathrm{t}_{0}=$ umur relatif (tahun)
\end{tabular}

2. Tingkat Mortalitas dan Tingkat Eksploitasi

Tabel 2. Nilai tingkat mortalitas alami, penangkapan, mortalitas total dan tingkat ekploitasi kerang pokea

\begin{tabular}{ccc}
\hline No. & Parameter & Nilai \\
\hline 1. & $\mathrm{M}$ & 1,84 \\
2. & $\mathrm{~F}$ & 1,19 \\
3. & $\mathrm{Z}$ & 3,03 \\
4. & $\mathrm{E}$ & 0,39 \\
\hline Keterangan : & $\mathrm{F}=$ Mortalitas akibat penangkapan \\
& $\mathrm{M}=$ Mortalitas alami & \\
& $\mathrm{Z}=$ Mortalitas total & \\
& $\mathrm{E}=$ Status eksploitasi
\end{tabular}

Penentuan tingkat eksploitasi kerang pokea terlihat dengan menganalisis tingkat mortalitas alami maupun mortalitas penangkapan. Perolehan nilai tingkat eksploitasi dapat diketahui jika nilai tingkat mortalitas alami (M) dan penangkapan (F) telah terhitung.

Berdasarkan hasil analisis dengan menggunakan analisis program FiSAT II versi 3.0 menunjukkan tingkat mortalitas alami dan penangkapan kerang pokea sebesar 1,84 dan 1,19. Mortalitas total pada kerang pokea sebesar 3,03.
Perolehan hasil analisis tingkat eksploitasi dari tingkat mortalitas alami dan akibat penangkapan sebesar 0,39. Nilai tersebut mengindikasikan bahwa tingkat eksploitasi kerang pokea masih berada dalam pemanfataan rendah (under fishing) (Tabel 2).

\section{Pembahasan}

\section{Pertumbuhan Kerang Pokea}

Pendugaan parameter pertumbuhan dapat diamati dengan metode von Bertalanffy dari hasil analisis kelompok ukuran dan didapatkan lebar asimtotik (Lo) dan konstanta pertumbuhan (K) melalui analisis program FiSAT II versi 3.0. Pertumbuhan lebar kerang pokea sangat cepat terjadi pada umur muda dan semakin lambat seiring dengan pertambahan umur sampai mencapai titik maksimum.

Lebar asimtotik $(\mathrm{L} \infty)$ merupakan nilai ratarata lebar kerang yang sangat tua (umur yang tidak terbatas) atau dengan kata lain tidak mampu lagi bertambah lebar. Nilai koefisien pertumbuhan $(\mathrm{K})$ merupakan penentu seberapa cepat kerang mencapai lebar asimtotiknya atau lebar maksimumnya (Sparre dan Venema, 1999). Panjang asimtotik yang digunakan adalah lebar pokea merujuk pada King (1995) dan Spare dan Venema (1999) bahwa kerang yang mempunyai ukuran lebar lebih besar daripada panjang, maka ukuran panjang digantikan dengan ukuran lebar.

Hasil analisis parameter pertumbuhan kerang pokea berdasarkan data sebaran frekuensi lebar selama 6 bulan menunjukkan nilai ukuran lebar infiniti $(\mathrm{L} \infty)$ 7,41 cm. Ukuran ini menunjukkan pertumbuhan cangkang kerang pokea sudah tidak dapat di capai lagi atau dengan kata lain ukuran yang tidak memungkinkan lagi bagi jenis kerang pokea untuk melakukan pertumbuhan atau bertambah lebar. Hal ini menyebabkan pemakaian energi yang tidak lagi digunakan untuk melakukan pertumbuhan melainkan hanya berguna untuk reproduksi maupun perbaikan sel-sel yang rusak.

Nilai koefisien pertumbuhan $(K)$ yaitu 0,56 , menggambarkan tingkat pertumbuhan kerang pokea untuk mencapai ukuran maksimal serta seberapa cepat pertumbuhan kerang pokea di perairan. Parameter $\mathrm{t}_{0}$ merupakan parameter kondisi awal yang menentukan umur ketika kerang pokea memiliki lebar nol. 
Tabel 3. Perbandingan parameter pertumbuhan kerang pada berbagai perairan

\begin{tabular}{lccccl}
\hline \multicolumn{1}{c}{ Lokasi } & Spesies & $\begin{array}{c}\text { Jenis } \\
\text { kelamin }\end{array}$ & K & Lo & Referensi \\
\hline Rataan Pasang Surut Backbarrier, & C. edule & - & 0,34 & 4,04 & Ramón, 2003 \\
Laut Wadden & T. gayi & - & 0,28 & 3,40 & Lomovasky, et al., 2005 \\
Teluk Ushuaia, Terusan Beagle & A. tuberculosa & - & 0,14 & 6,30 & Stern-Pirlot dan Wolff, 2006 \\
Pantai Pasific, Costa Rica & P. viridis & - & 1,50 & 10,20 & Al-Barwani et al., 2006 \\
Pantai Malakka, Jazirah Malaysia & M. squalida & - & 0,65 & 8,30 & Schweers et al., 2006 \\
Teluk Magdalena, Mexico & P. acutidens & - & 0,59 & 9,27 & Efriyeldi et al., 2012 \\
Dumai, Riau & B. violacea & Jantan & 0,71 & 7,84 & Bahtiar, 2012 \\
Sungai Pohara, Sulawesi Tenggara & Betina & 0,91 & 8,94 & Penelitian ini \\
Sungai Laeya Sulawesi Tenggara & B. violacea & - & 0,56 & 7,41 & P.
\end{tabular}

Keterangan :

$\mathrm{K}=$ Konstanta pertumbuhan

$\mathrm{L} \infty=$ Lebar asimtotik $(\mathrm{cm})$

Koefisien pertumbuhan total $(\mathrm{K})$ yaitu 0,56 per tahun merupakan parameter yang menggambarkan seberapa cepat kerang pokea mencapai lebar maksimum. Oleh karena itu, dapat dikatakan bahwa tingkat pertumbuhan kerang pokea membutuhkan waktu untuk mencapai nilai maksimum $(\mathrm{L} \infty)$. Hal ini didukung oleh Efriyeldi et al., (2012) bahwa koefisien pertumbuhan (K) merupakan parameter penting karena dapat menggambarkan tingkat pertumbuhan kerang untuk mencapai ukuran maksimal. Nilai ini dapat dipakai untuk membandingkan tingkat pertumbuhan kerang dengan jenis-jenis kerang lainnya yang berbeda maupun jenis yang sama dari habitat berbeda.

Parameter $t_{0}$ merupakan parameter kondisi awal ukuran atau umur ketika lebar sama dengan nol. Hal ini menunjukan pertumbuhan mulai dari saat telur menetas hingga pokea memiliki panjang/lebar tertentu. Hasil yang didapat menunjukkan nilai $t_{0}$ sebesar $-0,38$. Pertumbuhan lebar kerang pokea sangat cepat terjadi pada umur muda dan dewasa. Pertumbuhan produktif kerang pokea terjadi pada umur 0,46 tahun dengan mencapai lebar cangkang yaitu $4,03 \mathrm{~cm}$. Pertumbuhan kerang pokea akan semakin melambat seiring pertambahan umur sampai mencapai lebar maksimum pada umur 4,33 sampai 13,87 tahun dengan lebar cangkang 7,41 cm (Gambar 2). Sejalan dengan hasil penelitian (Nasrawati et al., 2016) bahwa kerang yang berumur muda memiliki pertumbuhan yang cepat dan seiring dengan pertambahan umur atau ketika mencapai umur tua maka laju pertumbuhannya akan lambat bahkan cenderung statis. Hasil yang tidak berbeda juga ditemukan pada ikan (Tilohe et al., 2014) menyebutkan bahwa pertumbuhan ikan pada umur satu tahun relatif cepat dan pada saat mencapai umur dua sampai tiga tahun pertumbuhannya mulai lambat dan sampai mencapai panjang tubuh maksimum.

Beberapa penelitian yang telah dilakukan memiliki perbedaan terhadap aspek pertumbuhan kerang pokea tersebut (Tabel 3). Perbandingan dengan kerang lainnya menunjukkan kerang pokea ini mempunyai konstanta pertumbuhan (K) tergolong cepat bila membandingkan konstanta pertumbuhan (K) kerang A. tuberculosa (SternPirlot dan Wolff, 2006) yang mempunyai nilai paling rendah dari semua nilai $(\mathrm{K})$, sehingga dapat disimpulkan bahwa nilai koefisien pertumbuhan ini dapat menjadi batas bawah dari semua nilai koefisien pertumbuhan yang ada. Nilai $\mathrm{K}$ yang berbeda terkait dengan tingkat metabolisme. Nilai $\mathrm{K}$ yang meningkat menunjukkan bahwa semakin cepat organisme mencapai lebar maksimum. Nilai $\mathrm{K}$ dipengaruhi dua hal yaitu dari spesies itu sendiri dan dari lingkungan. Jika nilai $\mathrm{K}$ tergolong kecil, maka kemungkinan kondisi habitat mengalami fluktuasi yang besar (Siswantoro, 2003).

\section{Tingkat Mortalitas}

Mortalitas merupakan penurunan stok dari suatu populasi menyebabkan tingkat kematian baik secara alami maupun akibat penangkapan dari individu tersebut. Kematian alami menyebabkan beberapa faktor antara lain: pemangsaan, penyakit, stres pemijahan, kelaparan, dan usia tua 
(Sparre dan Venema, 1999).

Hasil analisis menunjukkan tingkat mortalitas alami kerang pokea di Sungai Laeya tergolong tinggi dengan nilai mencapai 1,84 , sedangkan tingkat mortalitas penangkapan tergolong rendah yaitu 1,19. Artinya proses kematian atau kehilangan populasi kerang pokea yang terdapat di Sungai Laeya lebih banyak disebabkan oleh kematian alami. Berdasarkan nilai tersebut disimpulkan bahwa nilai mortalitas alami lebih besar bila dibandingkan dengan mortalitas penangkapan sehingga faktor lingkungan di perairan merupakan faktor pembatas (limiting factor) stok. Nilai mortalitas alami lebih tinggi daripada mortalitas akibat penangkapan juga disebabkan oleh adanya aktivitas penambangan yang terjadi di Sungai Laeya. Aktivitas penambangan pasir menjadi salah satu kegiatan masyarakat yang secara langsung berkontribusi besar sebagai penyebab penurunan kuantitas pokea pada saat penambangan. Hal ini ditujukan dengan kondisi beberapa tempat yang diambil pasirnya tidak ditemukan pokea yang hidup di daerah tersebut. Kematian bivalvia (Margaritifera margaritifera) seperti ini juga ditemukan pada aktivitas pengerukan substrat untuk kegiatan perikanan yang dapat merusak 5-10\% habitat bivalvia dan kematian bivalvia yang dapat mencapai 100-10.000 individu (Cosgrove dan Haltie, 2001), hilangnya 3\% Anodonta anatine dan 23\% A.cygnea (Aldridge, 2000). Kematian bivalvia juga dapat disebabkan oleh tingginya endapan liat sebagai akibat dari rusaknya habitat dari aktivitas penambangan pasir disungai (Bogan, 1993).

Nilai total mortalitas dan eksploitasi tersebut menggambarkan bahwa pemanfaatan pokea di Sungai Laeya tergolong pada kondisi perikanan yang kurang tangkap atau masih dibawah potensi lestarinya dengan nilai tingkat eksploitasi yaitu $\mathrm{E}=$ 0,39 . Untuk menjaga kelestarian dan kesinambungan penangkapan pokea di Sungai Laeya, nilai laju eksploitasi berada pada E optimum yaitu $\mathrm{E}=0$ 0,5. Menurut Gulland (1977) E optimum berada pada nilai maksimal 0,50 karena pada kondisi demikian maka diperoleh hasil tangkapan yang berkelanjutan.

Gambaran mengenai rendahnya penangkapan kerang pokea di Sungai Laeya terlihat pada frekuensi ukuran kerang pokea yang relatif stabil, dengan dominansi ukuran lebar kerang pokea pada tinggkat sedang/dewasa. Hal ini sesuai pernyataan Thangvelu et al., (2011) bahwa tingginya populasi ukuran kerang yang telah dewasa mengindikasikan bahwa spesies yang dieksploitasi berkategori sedang pulih. Perbandingan dengan kerang lainnya menunjukkan bahwa kerang pokea mempunyai tingkat mortalitas yang tergolong tinggi bila dibandingkan dengan tingkat mortalitas $A$. tuberculosa (Stern-Pirlot dan Wolff, 2006). Beberapa penelitian yang telah dilakukan disajikan pada Tabel 4.

Tingkat mortalitas berpengaruh erat terhadap fluktuasi suhu dengan asumsi bahwa semakin hangat suhu lingkungan semakin tinggi mortalitas alami (Sparred dan Venema, 1999). Nilai suhu rata-rata selama enam bulan penelitian di Sungai Laeya adalah $29,25^{\circ} \mathrm{C}$ dengan kisaran 28,23 $29,93^{\circ} \mathrm{C}$. Hasil ini menunjukkan kerang pokea masih dapat mentolerir suhu lingkungan perairan di Sungai Laeya, sebagaimana pernyataan Bahtiar (2005) dalam hasil penelitiannya bahwa suhu 26,1$31,4^{\circ} \mathrm{C}$ masih dapat menunjang pertumbuhan dan perkembangan populasi kerang pokea.

Tabel 4. Tingkat mortalitas kerang pada berbagai perairan

\begin{tabular}{|c|c|c|c|c|c|c|}
\hline Lokasi & Spesies & $\begin{array}{c}\text { Jenis } \\
\text { Kelamin }\end{array}$ & $\mathrm{Z}$ & M & $\mathrm{F}$ & Referensi \\
\hline Pantai Pasific, Costa Rica & A. tuberculosa & - & 0,48 & 0,14 & 0,34 & Stern-Pirlot dan Wolff, 2006 \\
\hline Sungai Pohara, Sulawesi & $B$ violacea & Jantan & 5,20 & 2,10 & 3,10 & \\
\hline Tenggara & B. violacea & Betina & 6,46 & 2,39 & 4,07 & Bahtiar, 2012 \\
\hline Teluk Kendari, Sulawesi & & Jantan & 3,20 & 1,74 & 1,46 & \\
\hline Tenggara & P. erosa & Betina & 3,56 & 2,46 & 1,10 & Tamsar, 2012 \\
\hline Sungai Volta, Ghana & G. paradoxa & - & 0,82 & 0,35 & 0,47 & Boateng dan Wilson, 2012 \\
\hline Estuari Kerala Utara, India & M. casta & - & 3,92 & 1,80 & 2,12 & Laxmilatha, 2013 \\
\hline Kolong, Karimun & A. granosa & - & 3,41 & 0,82 & 2,59 & Nuraini et al., 2014 \\
\hline Dumai, Riau & P. acutidens & - & 1,87 & 0,39 & 0,94 & Efriyeldi et al., 2012 \\
\hline $\begin{array}{l}\text { Sunagi Laeya, Sulawesi } \\
\text { Tenggara }\end{array}$ & B. violacea & - & 3,03 & 1,84 & 1,19 & Penelitian ini \\
\hline
\end{tabular}


Keterangan :

$\mathrm{F}=$ Mortalitas akibat penangkapan

$\mathrm{M}=$ Mortalitas alam

$\mathrm{Z}=$ Mortalitas total

\section{Tingkat Eksploitasi}

Tabel 5. Perbandingan nilai eksploitasi kerang pada berbagai perairan

\begin{tabular}{llccl}
\hline \multicolumn{1}{c}{ Lokasi } & \multicolumn{1}{c}{ Spesies } & Jenis Kelamin & E & Referensi \\
\hline Pantai Pasific, Costa Rica & A. tuberculosa & - & 0,71 & Stern-Pirlot dan Wolff, 2006 \\
Sungai Pohara, Sulawesi Tenggara & B. violacea & Jantan & 0,59 & Bahtiar, 2012 \\
Teluk Dumai, Riau & P. acutides & Betina & 0,63 & \\
Sungai Volta, Ghana & G. paradoxa & - & 0,50 & Efriyeldi et al., 2012 \\
Estuari Kerala Utara, India & M. casta & - & 0,57 & Boateng dan Wilson, 2012 \\
Laut Marmara Barat, Turki & D. trunculus & - & 0,54 & Laxmilatha, 2013 \\
Kolong, Karimun & A. granosa & & 0.02 & Çolakoğlu, 2014 \\
Sungai Laeya, Sulawesi Tenggara & B. violacea & - & 0,76 & Nuraini et al., 2014 \\
& & & 0,39 & Penelitian ini
\end{tabular}

Keterangan :

$\mathrm{E}=$ Tingkat eksploitasi

Penentuan tingkat eksploitasi kerang pokea dapat diketahui dengan menganalisis tingkat mortalitas alami maupun mortalitas penangkapan. Perolehan nilai tingkat eksploitasi dapat diketahui jika nilai tingkat mortalitas alami (M) dan penangkapan (F) telah terhitung. Fadly (2014) menjelaskan bahwa tingkat eksploitasi sumberdaya kerang suatu perairan merupakan nisbah antara produksi dengan besarnya potensi lestari atau sebagai hasil perbandingan antara besarnya kematian akibat penangkapan dengan besarnya total kematian. Evaluasi tingkat eksploitasi terhadap sumber daya sangat perlu agar pengelolaan sumberdaya tersebut bersifat rasional atau dapat lestari dan berkelanjutan.

Berdasarkan hasil analisis dengan menggunakan analisis program FiSAT II versi 3.0 menunjukkan tingkat ekploitasi pada kerang pokea di Sungai Laeya yaitu 0,39. Nilai tersebut menggambarkan bahwa tingkat eksploitasi kerang pokea di Sungai Laeya masih rendah atau berada di bawah potensi lestari. Hal ini sesuai dengan pernyataan Sparre dan Venema (1999) bahwa nilai tingkat ekploitasi kurang dari 0,50 menggambarkan kondisi pemanfaatan rendah (under eksploitasi). Hal ini menunjukkan pula terjadi penurunan intensitas waktu penangkapan (effort) yang dilakukan oleh nelayan setiap hari secara intensif dan berlangsung lama. Pernyataan ini didukung oleh Gulland (1983) bahwa tingkatan eksploitasi $(\mathrm{E})>0,5$ terkategori sebagai tingkat eksploitasi tinggi (over fishing), $(\mathrm{E})=0,5$ terkategori sebagai tingkat eksploitasi berimbang, dan eksploitasi (E) $<0,5$ terkategori sebagai tingkat eksploitasi rendah (under fishing). Beberapa penelitian yang telah dilakukan memiliki perbedaan terhadap aspek mortalitasnya. Selanjutnya Bell et al., (2011) menyatakan bahwa, tertangkapnya Batissa violacea dari $25 \%$ rata-rata stok yang ada di sungai dapat menjadi sumber daya yang berkelanjutan. Metode penangkapan yang masih tradisional dapat membantu mempertahankan populasi yang terdapat di dasar perairan. Penangkapan juga sangat terbatas setiap tahun dengan intensitas hujan yang tinggi karena nelayan tidak melakukan penangkapan selama banjir (under fishing).

Perbandingan dengan kerang lainnya menunjukkan bahwa kerang pokea ini mempunyai tingkat eksploitasi tergolong rendah bila dibandingkan dengan tingkat eksploitasi $A$. tuberculosa (Stern-Pirlot dan Wolff, 2006) dan A. Granosa (Nuraini et al., 2014) yang mempunyai nilai tertinggi dari semua tingkat eksploitasi dari jenis kerang yang telah tersaji (Tabel 5).

Kondisi ini akan terus berlangsung dengan baik jika bentuk upaya pelestarian terus meningkat mengingat potensi sumber daya kerang pokea sangat penting dan bermanfaat. Namun permasalahan terhadap tingkat kematian alami kerang pokea harus dapat di kelola melalui menjaga dan meningkatkan kondisi kualitas air di 
Sungai Laeya. Informasi tingkat eksploitasi tersebut sangat diperlukan untuk upaya dan kebijakan dalam bentuk pengelolaan agar sumber daya kerang pokea dapat berkelanjutan dengan tetap memerhatikan dan menjaga kelestarian sumber daya kerang pokea.

\section{Kesimpulan}

Pertumbuhan kerang pokea di Sungai Laeya menunjukkan nilai ukuran lebar infiniti (Lo) 7,41 $\mathrm{cm}$ dan koefisien pertumbuhan (K) 0,56. Mortalitas alami kerang pokea di Sungai Laeya lebih tinggi dibandingkan dengan mortalitas akibat penangkapan. Tingkat ekploitasi pada kerang pokea di Sungai Laeya relatif rendah yaitu 0,39.

\section{Daftar Pustaka}

Al-Barwani, S. M., Arshad, A., Amin, S. M. N., Japar, S. B., Siraj, S. S. \& C. K. Yap. (2006). Population Dynamics of the Green Mussel Perna viridis the High SpatFall Coastal Water of Malacca, Peninsular Malaysia. Fisheries Research. 84:147152.

Aldridge, D.C. (2000). The Impacts of Dredging and Weed Cutting on a Population of Freshwater Mussels (Bivalvia: Unionidae). Journal Biological Conservation 95: $247 \pm 257$

Anthony, J. L., Kesler, D. H., Downing, W. L. \& Downing, J. A. (2001). Length-Specific Growth Rates in Freshwater Mussel (Bivalvia : Unionidae): Extreme Longevity or Generalized Growth Cessation. Freshwater Biology. 46:1349-1359.

Bahtiar. (2005). Kajian Populasi Pokea (Batissa violacea celebensis Martens, 1897) di Sungai Pohara Kendari Sulawesi Tenggara. [Tesis] Sekolah Pasca Sarjana Institut Pertanian Bogor. Bogor. 140 Hal.

Bahtiar, Yulianda, F. \& Setyobudiandi, I. (2008). Kajian Aspek Pertumbuhan Populasi Kerang Pokea (Batissa violacea celebensis Martens, 1897) di Sungai Pohara Sulawesi
Tenggara. Jurnal Ilmu-ilmu Perairan dan Perikanan Indonesia. Jilid 15. 1:1-5.

Bahtiar. (2012). Studi Bioekologi dan Dinamika Populasi Pokea (Batissa violacea var. celebensis von Martens, 1897) yang Tereksploitasi Sebagai Dasar Pengelolaan di Sungai Pohara Sulawesi Tenggara. [Disertasi] Sekolah Pasca Sarjana Institut Pertanian Bogor. Bogor. 141 hal.

Bell, J. D., Johnson, J. E. \& Hobday, A. J. (2011). Vulnerability of Tropical Pasific Fisheries and Aquaculture to Climate Change. Chapter 10. Secretariat of Pasific Community, Noumea. New Caledonia. 576-646p.

Boateng, D. A. \& Wilson, J. G. (2012). Population Dynamics of the Freshwater Clam Galatea paradoxa from the Volta River, Ghana. Knowledge and Management of Aquatic Ecosystem Journal. 09:405p.

Bogan, A.E. (1993). Freshwater Bivalve Extinctions (Mollusca: Unionida): A Search for Causes. Amer Zool. 33:599609.

Çolakoğlu, S. (2014). Population Structure, Growth, and Production of the Wedge Clam Donax trunculus (Bivalvia, Donacidae) in the West Marmara Sea, Turkey. Turkish Journal of Fisheries and Aquatic Sciences. 14:221-230.

Cosgrove, P.J. \& Hastie, L.C. (2001). Conservation of Threatened Freshwater Pearl Mussel Population: River Management, Mussel Translocation and Conflict Resolution. Biological Conservation. 99. 183-190

Efriyeldi, Bengen, D. G., Affandi, R. \& Prartono, T. (2012). Karakteristik Biologi Populasi Kerang Sepetang (Pharella acutidens) di Ekosistem Mangrove Dumai, Riau. Jurnal Perikanan Terubuk. 40(1):36-44.

Fadly, F. (2014). Tingkat Eksploitasi dan Keragaan Pertumbuhan Kerang Darah (Anadara 
granosa) pada Perairan Kuala Penet, Labuhan Maringgai, Lampung Timur. [Skripsi] Fakultas Perikanan dan Ilmu Kelautan. Institut Pertanian Bogor. Bogor. 29 hal.

Gayanilo, F. C. Jr. \& D. Pauly. (1997). FAOICLARM Stock Assessment Tools (FiSAT). Reference Manual, Rome, FAO. 9(2):47-49.

Gulland, J.A. (1977). Fish Population Dynamics. The Implications of Management. A Willey-Inter Science Publication. 2 nd $\mathrm{ed}$. John Willey and Sons Ltd. 102p.

Gulland, J. A. (1983). Fish Stock Assesment: Manual of Basic Methods. Chichester, United Kingdom. Wiley Inter Science, FAO/Wiley Series on Food and Agriculture. 1:223p.

Islami, M.M. (2014). Bioekologi Kerang Kerek Gafrarium tumidum Röding, 1798 (Bivalvia: Veneridae) Di Perairan Teluk Ambon, Maluku. [Tesis] Sekolah Pascasarjana Institut Pertanian Bogor

King M. (1995). Fisheries Biology, Assessment, and Management. Fishing News Books. London, United Kingdom England. 341 hal.

Laxmilatha P. (2013). Population Dynamics of the Edible Clam Meretrix Casta (Chemnitz) (International Union For Conservation of Nature Status: Vulnerable) From Two Estuaries of North Kerala, South West Coast of India. International Journal of Fisheries and Aquaculture. 5(10):253-261.

Lomovasky, B. J., T. Brey. \& E. Marriconi. (2005). Population Dynamics of the Venerid Bivalve Tawera gayi (Hupé, 1854) in the Ushuaia Bay, Beagle Channel. Journal Application Ichthyologia. 21:64-69
Nasrawati, Bahtiar \& L. Anadi. (2016). Pertumbuhan, Kematian, dan tingkat Eksploitasi Kerang Coklat (Modiolus modulaides) di Perairan Teluk Kendari Sulawesi tenggara. Jurnal Sains dan Inovasi Perikanan, 1(1) : $1-8$.

Natan, Y. (2009). Parameter Populasi Kerang Lumpur Tropis Anodonta edentula di Ekosistem Mangrove. Jurnal Biologi Indonesia. 6(1):25-38.

Nuraini., Zulfikar, A. \& Raza'I, T. S. (2014). Kajian Stok Kerang Darah (Anadara granosa) Berbasis Panjang Berat yang didaratkan di Daerah Kolong Kabupaten Karimun. Jurnal Skripsi. Jurusan Manajemen Sumber Daya Perairan. Fakultas Ilmu Kelautan dan Perikanan. Universitas Maritim Raja Ali Haja. Riau. 14 hal.

Nurdin, J., N. Marusin., Izmiarti., A. Asmara., R. Deswandi \& J. Marzuki. (2006). Kepadatan populasi dan pertumbuhan kerang darah (Anadara antiquata $L$ (Bivalvia : Arcidae) di Teluk Sungai Pisang, Kota Padang Sumatera Barat. Makara Science, 10 (2):96- 101.

Pauly, D. (1980). On the Interrelationships Between Natural Mortality, Growth Parameters and Mean Environmental Temperature in 175 Fish Stocks. J. Cons. CIEM, 39 (2): 175-192.

Putri ER. (2005). Analisis Populasi dan Habitat Sebaran Ukuran dan Kematangan Gonad Kerang Lokan Batissa violacea Lamarck (1818) di Muara Sungai Batang Anai Padang Sumatera Barat. Pasca Sarjana. Institut Pertanian Bogor. Bogor. 62 hal.

Ramón, M. (2003). Population Dynamics and Secondary Production of the Cockle 
Cerastodema edule in a Backbarrier Tidal Flat of the Wadden Sea. Scientia Marina. 67(4):429-443.

Schweers, T., Wolff, M., Koch, V. \& Duarte, F. S. (2006). Population Dynamics of Megapitaria squalida (Bivalvia: Veneridae) at Magdalena Bay, Baja California Sur, Mexico. International Journal Tropical Biology. 54(3):10031017.

Siswantoro, B. (2003). Kajian Tentang Pertumbuhan dan Penyebaran dari Meretrix meretrix di Pantai Jenu Kabupaten Tuban. [Jurnal Skripsi] Fakultas Perikanan dan Ilmu Kelautan. Institut Pertanian Bogor. Bogor. 70 hal.

Sparre, P. \& S. C. Venema. (1999). Introduction to Tropical Fish Stock Asassment. Rome. FAO. Italy. 436 Hal.

Stern-Pirlot, A. \& Wolff, M. (2006). Population Dynamics and Fisheries Potential of Anadara tuberculosa (Bivalvia: Arcidae) along the Pasific Coast of Costa Rica. Revista de Biología Tropical. 54(1):87-100.

Tamsar. (2012). Studi Pertumbuhan dan Tingkat Eksploitasi Kerang Kalandue (Polymesoda erosa) pada Daerah Hutan Mangrove di Teluk Kendari Sulawesi Tenggara. [Skripsi] Fakultas Perikanan dan Ilmu Kelautan. Universitas Halu Oleo. Kendari. 50 hal.

Thangavelu, A., David, B., Barker, B., Geneste, J. M., Delannoy, J. J., Lamb, L., Araho, N. \& Skelly, R. (2011). Morphometric Analyses of Batissa violacea Shell from Emo (OAC), Gulf Province, Papua New Guinea. Archeology Oceania. 46:67-75.
Tilohe, O., Nirsinar, S. \& Salam, A. (2014). Analisis Parameter Dinamika Populasi Ikan Cakalang yang di Daratkan di Pangkalan Pendaratan Ikan Kelurahan Tenda Kota Gorontalo. Jurnal Ilmiah Perikanan dan Kelautan. Volume II. Nomor 4. Hal 1-6. 